Po rozważeniu różnych aspektów religijnego ujęcia życia-szczęścia, odpowiedź na pytanie, czym jest życie w oparciu o Księgę Psalmów, może być następująca:

W Księdze Psalmów, jak w całym Starym Testamencie, ,życie” jako przejaw różnych form oddziaływania Bożego skierowanych ku wypełnieniu planu dziejowego co do narodu wybranego może być uważane za metaforę zbawczą, natomiast jako cel tych dążeń i zabiegów, czyli jako pełne zjednoczenie z Bogiem, ,życie” jest synonimem zbawienia. Dlatego też $w$ oparciu o słownictwo oznaczające zbawienie, jak i o rozpatrywane metafory zbawcze (łącznie $\mathrm{z}$ metafora życia!) można zbawienie określić następująco:

ZBAWIENIE w Księdze Psalmów stanowi wynik działania Bożego i świadomych wysiłków ludzkich podejmowanych w ramach wybranej społeczności dla ocalenia, przedłużenia i wzbogacenia życia ludzkiego, a ostatecznie zmierzających do uzyskania pełni życia $w$ zjednoczeniu z Bogiem.

Zbawienie $w$ takim ujęciu ma charakter tylko pozytywny, nie zawiera idei ekspiacji, naprawy zerwanych stosunków z Bogiem czy zadośćuczynienia. Charakteru ekspiacyjnego jednak nie ma też ,odkupienie" Izraela dokonane przez Jahwe w dziejach zbawczych Starego Przymierza.

Zakończyć można niniejsze rozważanie na temat zbawienia jako życia modlitwą psalmisty z 85, 3. 7-8: „Odpuściłeś winę swojemu ludowi i zakryłeś wszystkie jego grzechy. ... Czyż to nie Ty przywrócisz nam życie, a Twój lud w Tobie będzie się weselił? Okaż nam, Panie, laskę swoją i daj nam swoje zbawienie!".

Warszawa

O. JÓZEF W. ROSEON OFMConv

Ks. Andrzej Strus SDB

\title{
ROZWÓJ PROROCTWA O EMMANUELU JAKO PRZYKLAD HERMENEUTYKI W STARYM TESTAMENCIE
}

$\mathrm{Na}$ temat proroctwa Izajasza o Emmanuelu napisano wiele monografii i artykułów wraz $z$ niezliczoną ilością propozycji jego interpretacji ${ }^{1}$. Zadaniem niniejszego artykułu nie jest obalanie czy uzu-

1 Obszerną bibliografię doprowadzoną do 1969 r. znaleźć można w: H. W il d berger, Jesaja 1-12 (Biblischer Kommentar. Altes Testament, Bd X/1), Neukirchen 1922, 262-264 i 300. Po r. 1969 odnotowujemy następujące pozycje: P. A uvray, Isaïe 1-39 (Sources Bibliques), Paris 1972; N. Lohfink, Bibelquslegung im Wandel. Ein Exeget ortet seine 
pełnianie nową hipotezą tego, co już dotychczas powiedziano. Pragniemy raczej zwrócić uwagę na warianty tekstowe, jakie zawiera perykopa Iz 7, 10-17, i przebadać ich funkcję znaczeniową w kontekście perykopy na przestrzeni czasu od VIII w. przed Ch. do pism qumrańskich. Naszym zdaniem te warianty są świadkami ,̇̇ycia tekstu" i odsłaniają nam tajemniczy dialog tego tekstu z następującymi po sobie pokoleniami wierzących Izraela. Inaczej mówiąc, są to dostrzegalne znaki tchnienia (in-spiratio) Ducha Św. na słowo Boże sformułowane przez proroka w VIII w. i przekazywanie przez pokolenia, które, tym samym Duchem wiedzione, wyjaśniały i pogłębiały ludzkie zrozumienie słowa. Spełniają one wreszcie rolę drogowskazów procesu hermeneutycznego, w którego nurcie tekst Izajasza przedzierał się ku osiągnięciu swej pełni znaczeniowej w Nowym Testamencie.

Hermeneutyka wewnątrzbiblijna tekstów starotestamentowych jest faktem uznanym. Wystarczy porównać w Pięcioksięgu pewne opowiadania wspólne tradycjom J, E i P, by się o tym przekonać. Trudniej jest $\mathrm{z}$ opisaniem metody hermeneutyki wewnątrzbiblijnej. Znane już prace poświęcone naturze i metodzie hermeneutyki starożytnej w literaturze pozabiblijnej i $\mathrm{w}$ pismach rabinistycznych ${ }^{2}$ zachęcają, by pogłę̧bić tę problematykę także wewnątrz tekstów biblijnych w oparciu o porównanie tekstu oryginalnego, jego wariantów i jego przykładów.

Za jedną z pierwszych prób podjęcia badań w tym kierunku należy uważać pracę I. Willi Plein i J. Koeniga ${ }^{8}$. Szczególnie ostatnia mo-

Wissenschaft, Frankfurt a/M 1976, 186-188; F. Dre yfus, L'actualisation à l'intérieur de la Bible, RB 83 (1976), 188-200; E. T es ta, I Salvatori apocalittici d'Israele: la Partoriente e il sou NATO, ,Marianum" XL (1978), 31-40; R. P. Carrol, When Prophecy Failed Reactions and Responses to Failure in the Old Testament Prophetic Traditions, London 1979, 138-141. Z polskich opracowań na szczególną uwagę zasługuje wnikiiwa anaiiza proroctwa Izajasza w artykule: M. Gołę bie w ski, Mesjanizm Księgi Izajasza na tle historii $i$ tradycji Izraela, At Kapł 451 (1984), 389-406. Autor przytacza w krótkiej syntezie różne opinie dotyczące znaku Emmanuela i matki dziecka mesjańskiego oraz podaje najnowsze pozycje bibliograficzne dotyczące tego zagadnienia, str. 393.

2 Obszerną bibliografię zebraną na ten temat do r. 1967 można znaleźć w artykule: J. Coppens, L’herméneutique biblique, w: Exégèse et Théologie. Donum natalicium J. Coppens, vol. III, Gembloux 1968, 283315 (wyd. G. Thils i R. E. Brown). Na temat egzegezy rabinistycznej źródłowym dziełem jest: J. Bonsirven, Exégèse rabbinique et exégèse paulinienne, Paris 1939. Wśród innych dzieł $\mathrm{z}$ tego zakresu cytujemy: O. Loretz - W. Strolz (wyd), Die hermeneutische Frage in der Theologie, Freiburg 1968; G. Vermes, Postbiblical Jewish Studies, Leiden 1975; D. W. Go od ing, Relics of Ancient Exegesis (The Soc. for OT. Nionogr. Series 4), Cambridge 1976.

3 Ina Willi Ple in, Vorformen der Schriftexegese innerhalb des Alten Testaments, BZAW 123, Berlin 1971; J. K o enig, L'herméneutique cnalogique du judaisme antique d'après les témoins textuels d'Isaïe, (Suppl. to VT XXXIII), Leiden 1982. 
nografia zasługuje na baczną uwagę, gdyż zajmuje się ona analizą współzależności między wariantami tekstowymi TM i LXX w księdze Izajasza a procesem hermeneutycznym, mającym miejsce $w$ łonie wspólnoty judaistycznej z III i II w. przed Chr. J. Koenig analizuje szczegółowo wszystkie warianty tekstowe Izajasza, by dojść do wniosku, że ówczesna hermeneutyka posiadała charakter transformatyczny, tzn. wpływała na przekształcenie tekstu hebrajskiego ${ }^{4}$. Jego zdaniem hermeneutyka transformatywna wywarla tak silny wpływ na formowanie się tekstu Księgi Izajasźa, iż przyczyniła się do powstania dwu grup tekstowych: $\mathrm{z}$ jednej strony grupa tekstów o charakterze popularno-pouczającym, zawierających dużą ilość dowolnych wariantów, $z$ drugiej strony grupa tekstów o charakterze normatywnym odznaczających się ogólną stabilnością. Pierwsza grupa zachowała się w rękopisach z Qumran, w przekładach LXX, Syr i Teodocjana, a później odnalazła się w egzegezie rabinistycznej; druga grupa znalazła swe miejsce w wersjach, z których powstał później TM, w niektórych rękopisach $\mathrm{z}$ Qumran i w przekładzie Hexapli ${ }^{5}$.Tekst normatywny miał być, zdaniem Koeniga, zarazem i źródłem dla tekstów popularno-pouczających, i stałą podstawą gwarantującą metodyczne ich przekształcanie.

Jeśli przekształcenia tekstowe dokonywane na drodze procesu hermeneutycznego obejmowały stosunkowo latwo teksty popularno-pouczające, w wypadku tekstów normatywnych pojawiały się one raczej wyjątkowo. W pierwszej grupie przekształcenia te dyktowane były potrzebą wyjaśniania i pouczania wspólnoty religijnej, natomiast w drugiej przyczyną ich powstania mogły być tylko wyjątkowe potrzeby doktrynalne. Niezależnie jednak od różnicy ilościowej obydwu rodzajów przekształceń tekstu, ich obecność zarówno w pierwszej jak i w drugiej grupie świadczyłaby o ogromnym wpływie hermeneutyki na kształtowanie się ostatecznej formy tekstów natchnionych ST.

Ubocznie należy dodać, że wnioski Koeniga zdają się znajdować pośrednio potwierdzenie $\mathrm{w}$ rezultatach badań nad ostatecznym formowaniem się tekstów Jeremiasza i Ezechiela. Wyniki analizy porównawczej niektórych fragmentów TM i LXX z Ezechiela przedstawione przez J. Lusta i szczególnie M. Bogaerta podczas ostatniej sesji Kollokwiów Biblijnych w Leuwen w sierpniu 1985 r. potwierdzają W dużej mierze tezę J. Koeniga ${ }^{6}$.

4 Autor stwierdza na str. 405: „Analizy poświęcone zmianom tekstu opartym na analogii tekstów pisanych i na formalnej analogii materiałów z. tradycji ustnej w Qa doprowadziły do uznania stałej, która zmusza do poszerzenia pojęcia hermeneutyki. Owczesna hermeneutyka posługiwała się metodami wychodzącymi poza ramy interpretacji tekstu biblijnego (...) wnikała ona również w substancję tekstu hebrajskiego; była to hermeneutyka przeksztaicająca (,elle a été tranformante”).

5 Tamże, str. $411 \mathrm{n}$.

${ }^{6} \mathrm{~J}$. Lust, Ezekiel and his Book, Coll. Bibl. Lovaniense XXXV; M. Bogaert, Les deux rédactions conservées ( $L X X$ et TM) d'Ezéchiel 7, Coll. Bibl. Lovaniense XXXV (27-29. 08. 1985). 
Pozostaje oczywiście do wyjaśnienia problem jakości znaczeniowej i zakresu formalnego tych przeobrażeń tekstu. Koenig przyjmuje w oparciu o tekst Izajasza, że dotyczą one raczej pojedynczych słów, ale w taki sposób, że zmieniają zasadniczo sens całej wypowiedzi. Porównania TM i LXX w wypadku Jeremiasza i Ezechiela wskazują na większe rozbieżności formalne i treściowe i wymagają osobnego omówienia. Ten problem pozostawiamy jednak na uboczu, gdyż wychodzi on poza ramy zakreślonego zagadnienia. Przyjmując wnioski Koeniga, oczywiście w charakterze hipotezy roboczej, za punkt wyjściowy dla proponowanej analizy tekstu Iz 7, 10-17 pragniemy zwrócić jeszcze uwagę na pewną zbieżność, jaka istnieje między tą hipotezą a jednym $\mathrm{z}$ czterech podstawowych działań procesu hermeneutycznego, określonych przez P. Ricoeura jako „odkrycie świata tekstu" ". Przez ,świat tekstu" Ricoeur rozumie odniesienie się opowiadania, spisanego i $\mathrm{w}$ takiej formie przekazywanego odbiorcom do rzeczywistości, jaką ono reprezentuje. "Odkrycie świata tekstu” jest dla filozofa francuskiego wejściem w jego rzeczywistość, przy czym jest to działanie bardziej subiektywne niż obiektywne. Czytelnik odkrywa świat tekstu, gdy znajduje w nim propozycje swego świata, tzn. propozycję świata, w którym może zrealizować swoje najwłaściwsze możliwości ${ }^{8}$. Taka interpretacja kładzie nacisk na świat poetycki tekstu, na jego dystans w odniesieniu do rzeczywistości codziennej i na jego otwarcie się $w$ kierunku czytelnika. Trudno przyjąc ją w całej pełni, rezygnując już w punkcie wyjściowym - jak to czyni właśnie Ricoeur - z poszukiwania uwarunkowań psychospolecznych tekstu, czyli intencji autora. Ustosunkowujemy się krytycznie do tak dalece posuniętego rozumienia świata tekstu i - uważając za bardziej słuszne zadania, jakie wytycza hermeneutyce F. Dreyfus ${ }^{9}$ rozumiemy "odkrycie świata tekstu" jako zrozumienie zarówno jego formy poetycko-literackiej jak też jego uwarunkowań psycho-spolecznych (tekst - autor - środowisko).

Współczesna hermeneutyka może określić sobie takie zadania dzięki posiadaniu bogatych środków umożliwiających jego realizację, jak dane historyczne, archeologiczne, epigraficzne, itd. Starożytna hermeneutyka była oczywiście ograniczona w tym względzie. Nie mogła ona wytyczyć sobie podobnego zadania ze względu na brak środków do jego spełnienia. Nie znaczy to jednak, że starożytni rezygnowali z potrzeby przelamania dystansu między rzeczywistością tekstu

7 „Découvrir le monde du texte”. Zob. P. Ricoeur, La tâche de l'herméneutique w: Exegesis. Problèmes de méthode et exercise de lecture, wyd. G. Rouiller, Neuchâtel - Paris 1975, 179-228; szczególnie str. 210213 i $221 \mathrm{nn}$.

8 Tamże, str. 213.

${ }^{9}$ F. D re y f u s określił model hermeneutyki biblijnej w serii artykulów publikowanych w "Revue Biblique" nr 82-86 (1975-1979). Tutaj odwołujemy się do artykułu pt. Exégèse en Sorbonne. Exégèse en Eglise, RB 82 (1975), 345. 
i światem jego odbiorców. W wypadku gdy tekst stawał się niezrozumiały, starożytna hermeneutyka zmuszona była zbliżyć tekst do podmiotu nie na drodze odkrycia ,świata tekstu", lecz poprzez dostosowanie tekstu do świata podmiotu. Pociaggało to za sobą przekształcenie tekstu celem dostosowania go do nowej rzeczywistośzi jego odbiorców. $Z$ tego rodzaju procesem hermeneutycznym należy wiązać, naszym zdaniem, takie zjawiska jak przekształcenia tekstu w Księgach Proroków, istotne warianty tekstowe w Księgach Prawa czy tzw. relekturę telistu w Psalmach. W świetle powyższych wyjaśnień pragniemy obecnie przejść do konkretnego tekstu, do perykopy zawierającej pierwsze proroctwo o Emmanuelu w Iz 7, 10-17.

\section{RZECZYWISTOŚĆ HISTORYCZNA PERYKOPY I JEJ PRZEOBRAŻENIA}

Uwarunkowania historyczne tekstu zawierającego pierwsze proroctwo Izajasza o Emmanuelu są dokładnie określone przez samego proroka. Kontekst poprzedzający perykopę pozwala szczegółowo określić historyczne wymiary proroctwa ${ }^{10}$. Miejscem jego ogłoszenia jest Jerozolima, stolica Judei, osobami biorącymi udział: prorok Izajasz i król Judei Achaz, sytuacją polityczną oblężenie Jerozolimy przez sprzymierzone wojska Syrii i Efraima, przerażenie mieszkańców stolicy i władcy, wskazówlką chronologiczną prawdopodobnie rok 74 przed Chr. Wobec zagrożenia i lęku prorok występuje w imieniu Boga i ogłasza królowi wyrocznię zapewniającą pomyślne zakończenie konfliktu. Żąda jedynie pełnego i całkowitego zawierzenia Bogu: „Jeżeli nie uwierzycie, nie ostoicie się" (w. 9). Dla poparcia prawdziwości swych słów Izajasz poleca królowi, by zażądał znaku od Boga. Na odmowną odpowiedź władcy, okazującego brak zaufania „,swemu Bogu", prorok sam podejmuje inicjatywę i zapowiada królowi znak, jaki ten otrzyma od Boga. Ta właśnie wymiana zdań między prorokiem a królem, jak też napiętnowanie władcy za brak wiary i zaufania Bogu oraz zapowiedź samego znaku, stanowią treść omawianej przez nas perykopy.

Jaka jest natura zapowiedzianego znaku? Proroctwo Izajasza objęte wspólnym mianem znak, "dlatego Pan sam da wam znak", zawarte jest $\mathrm{w}$ ww. 14-17 i obejmuje dwa elementy strukturowe: zapowiedź Emmanuela o charakterze raczej ogólnym i bliżej nieokreślonym, ww. 14-15, oraz wyrocznię o charakterze konkretnym i określonym historycznie w ww. 16-17.

10 Ustalenie rzeczywistości historycznej danego tekstu biblijnego jest pierwszym zadaniem egzegezy i temu zadaniu poświęcają najwięcej miejsca komentarze biblijne. Na temat perykopy Iz 7, 10-17 zob. bibliografię podaną $w$ przypisie 1 . 
Pierwszy element, nazwijmy go ,zapowiedź wydarzenia”, jest bardzo ogólnikowy i nie pozwala na bliższe określenie ,świata tekstu”. Brak bliższego określenia dotyczy zarówno podmiotu, jak też relacji czasowej między podmiotem i przedmiotem i wreszcie samego przedmiotu. Podmiotem zapowiedźi jest halalmah, młoda niewiasta fizycznie zdolna do macierzyństwa. Mimo rodzajnika, słowo to pozostaje wieloznaczne w swym kontekście. Kogo prorok wskazuje mówiąc halalmah? czy swoją żonę, o której będzie mowa dopiero w 8, 3, czy małżonkę Achazą, którą w takim wypadku winien - zgodnie $\mathrm{z}$ formą podobnych zapowiedzi w ST - wymienić po imieniu z dodatkiem określenia „Twoja żona”, np. Sara, „twoja żona” w Rdz 18, 10, czy wreszcie jakąkolwiek niewiastę, której sam prorok nie ma zamiaru bliżej określić? Mimo szeroko rozpowszechnionej a naszym zdaniem nieuzasadnionej opinii, że halalmah oznacza żonę Achaza, uważamy, że nie należy zmuszać tekstu do powiedzenia tego, czego on nie mówi i pozostajemy przy anonimowości tajemniczej halalmah ${ }^{11}$. Relację między podmiotem i przedmiotem zapowiedzi prorockiej wyrażają dwa czasowniki w formie imiesłowowej: harah weyoledet, co dosłownie można by przetłumaczyć przez „Brzemienna i rodząca”. Forma imiesłowowa nie pozwala na bliższe określenie czasowe tego wydarzenia ${ }^{12}$; można powiedzieć, że prorok wybrał celowo formę nominalną, by uniknąć konieczności określania czasu wydarzenia.

Przedmiotem zapowiedzi jest dziecię już narodzone lub mające się narodzić, które otrzyma imię Emmanuel. Imię jest symboliczne $i$, podobnie jak w wypadku dwóch innych imion symbolicznych u Izajasza Szearjaszub i Maher-Szalal-Hasz-Baz winno zapowiadać jakąś nadzwyczajną sytuację, korzystną lub bolesną dla narodu. W wypad$\mathrm{ku}$ dwu pozostałych imion prorok określa bliżej tę sytuację, wyjaśniając równocześnie symbolikę imion. W tym wypadku takiego wyjaśnienia nie ma; pojawi się ono $w$ trzech następnych proroctwach o Emmanuelu, Iz 8, 9-10; 9, 5-6 i 11, 1-5, ale właśnie z nich dowiadujemy się, że symbolika imienia Emmanuel odnosi się nie tyle do przyszłej sytuacji Judy, ile raczej do osoby samego dziecka i do szczególnej roli, jaką ono odegra w dziejach narodu czy raczej narodów. Utożsamienie historyczne Emmanuela jest więc dodatkowo utrudnione i ta właśnie postać enigmatyczna oddala jeszcze bardziej

11 Świadectwem poliwalencji znaczeniowej słowa 'almah jest rozbieżność w jego interpretacji. Komentarz $\mathrm{H}$. Wildbergera podaje osiem różnych interpretacji tego słowa, str. 289-292. J. B e cker, Isaias, der Prophet und sein Buch (SBS), Stuttgart 1968, sprowadza wszystkie interpretacje od trzech zasadniczych: 'almah jest jakąś nieznaną niewiastą, której Izajasz nie określa bliżej; jest żoną króla Ezechiasza; jest żoną samego proroka, str. 31.

12 To zdanie imiesłowowe można przełożyć w poczwórny sposób: „pocznie i porodzi", ,poczęła i porodzi", ,poczęła i rodzi”, ,poczęła i porodziła". Kontekst zdaje się przemawiać za pierwszą możliwością, składnia hebrajska wskazuje raczej na drugą lub trzecią, zob. P. A uv ray, Isaïe; str. 101 i $104 \mathrm{n}$. 
tekst proroka od jakiejkolwiek rzeczywistości historycznej. W tym miejscu należy zapytać, w jakim sensie obraz bliżej nieokreślonej niewiasty i jej dziecka jest znakiem dla Achaza. Z konstrukcji gramatycznej zdania: „dlatego sam Pan da wam znak: oto młoda niewiasta pocznie i porodzi syna" wynikałoby, że prorok tymi właśnie słowami określa istotę znaku; jednak brak bliższego określenia czasu i osób, określenia niezbędnego do tego, by znak był czytelny, sprzeciwia się takiemu mniemaniu. Kiedy w ST Bóg lub posłaniec Boży zapowiada jakiś znak, czyni to w sposób zrozumiały i pozwalający określić się w konkretnej sytuacji. Gdy Abraham pyta o znak spełnienia się obietnicy otrzymania ziemi Kanaan, Jahwe każe mu przygotować ryt przymierza (Rdz 15, $18 \mathrm{nn})$ : gdy Mojżesz wątpi, czy Izraelici uwierzą jego posłaniu, Bóg każe posłużyć się znakami: laska zamieniona w węża, ręka pokryta trądem, woda z Nilu zmieniona w krew (Wj 4, 1-9); gdy Gedeon prosi o znak na potwierdzenie, że będzie zdolny pokonać Madianitów, anioł Pański dotyka końcem laski mięso i chleby złożone na skale i sprowadza na nie ogień $z$ nieba ( $\mathrm{Sdz} 6$, 17-21). Można by mnożyć przykłady na potwierdzenie tej fundamentalnej zasady znaku, a mianowicie, że do jego istoty należy czytelność i zdolność do zrozumienia go jako znaku ze strony tych osób, którym jest podany. W pierwszym zdaniu proroctwa Izajasza żaden $z$ trzech elementów nie spełnia tego warunku. Każdy z osobna i wszystkie razem ukazują sytuację czasowo i historycznie nieokreśloną i nie funkcjonują same w sobie jako znak zrozumiały dla odbiorców. Istota znaku w proroctwie o Emmanuelu musi zatem tkwić nie w zapowiedzi narodzenia dziecka, lecz w następnych zdaniach ${ }^{13}$.

Konkretne i określone odniesienie do rzeczywistości historycznej znajdujemy $w$ drugiej części proroctwa, ww. 16-17. Mamy tu do czynienia z tzw. wyrocznią ocalenia dla Judy, dotyczącą niedalekiej przyszłości i dającą się bez trudu utożsamić w kontekście społeczno-politycznym. Chodzi o zapowiedź zniszczenia Syrii w r. 732 i następnie Królestwa północnego, Efraima, w r. 722. Prorok zapowiada, że okres ten będzie dla dynastii dawidowej okresem dobrobytu i że znamionować go będą dobra charakterystyczne dla Ziemi Obiecanej, jak śmietana i miód jako posiłek, oraz pokój powszechny przypominający czasy Salomona. Ta część proroctwa jest określona w czasie i miejscu; dotyczy ona Achaza jako następcy na tronie Dawida i jego rządów w najbliższej przyszłości: „Na twój lud i na dom twego ojca ześle Pan czasy, jakich nie było od schizmy". Ponieważ wyrocznia ta jest ściśle związana $\mathrm{z}$ zapowiedzią narodzin tajemniczego Emmanuela, możemy powiedzieć, że w niej właśnie tkwią elementy niezbędne do tego, by znak Emmanuela był czytelny. Jeśli trudno do-

${ }^{13} \mathrm{Na}$ temat natury i istoty znaku w naszej perykopie istnieją osobne opracowania, zob. bibliografię w: H. Wild berger, Jesajạ 1-12, str. 263 n. Dość wnikliwie i syntetycznie omawia to zagadnienie $H$. W. W o Iff, Frieden ohne Ende (Biblische Studien, 35), Neukirchen 1962, str. 41-47. 
strzec charakter znaku w ogólnej i mało precyzyjnej zapowiedzi narodzin, jeśt on łatwo dostrzegalny w określeniu okoliczności, które wkrótce po tych narodzinach nastąpią. Wbrew więc pozornej oczywistości, jaka zdaje się wynikać z konstrukcji gramatycznej zdania, znak Emmanuela polega nie tyle na narodzinach Dziecka, które nie są bliżej określone, ile na sytuacji, jaka nastąpi wkrótce po tym wydarzeniu. Sens wypowiedzi prorockiej odsłania się w tym tekście w kierunku odwrotnym do jego konstrukcji syntaktycznej. W tzw. z.naku Emmanuela tym, co stanowi właściwy znak, jest nie zapowiedź narodzin Dziecka, lecz wyrocznia dotycząca zniszczenia ziemi nieprzyjaciół Achaza i dobrobytu jego państwa. Tym, co jest dobrem zbawczym proponowanym przez Boga dynastii dawidowej jest nie wyborny pokarm i dobrobyt przypominający czasy Salomona, lecz narodzenie Emmanuela i jego władza w domu Dawida. Sumując możemy powiedzieć, że tekst proroctwa zawiera zapowiedź daną Achazowi i jego ludowi, iż wkrótce narodzi się tajemniczy władca, który jak wiemy $z$ następnych proroctw o Emmanuelu - ustanowi pokój powszechny wśród narodów oraz znak poprzedzający nadejście panowania Emmanuela, określony w konkretnych wydarzeniach historycznych, którymi będą uwolnienie Judy od nieprzyjaciół i okres dobrobytu nieznanego od czasów schizmy. Takie zrozumienie wyrażenia się znaku w proroctwie o Emmanuelu odpowiada licznym przykładom ze ST, w których znajdujemy obydwa elementy: zapowiedź interwencji Boga przynoszącej ludowi dary zbawienia i znak dany na jej potwierdzenie ${ }^{14}$. Podobnie jak w przytoczonych powyżej przykładach Abrahama, Mojżesza, Gedeona czy w NT w przykładzie Zwiastowania, nasz tekst zawiera i zapowiedź nadzwyczajnego wydarzenia zbawczego ofiarowaną przez Boga w sytuacji niesprzyjającej takiemu wydarzeniu, i znak towarzyszący tej zapowiedzi i potwierdzający jej prawdziwość. Zapowiedź dóbr zbawienia ma charakter ogólny, znak jest natomiast, konkretny dostrzegalny i sprawdzalny.

Przejdźmy $\mathrm{z}$ kolei do wariantów tekstowych perykopy świadczących o wplywie hermeneutyki transf rmacyjnej na jej tekst. Do istotniejszych wariantów zaliczamy trzy następujące ${ }^{15}$ : w wierszu 14

11 Według naszej interpretacji ,znak” podany przez Izajasza nie może być oddzielony od zapowiedzi zbawienia i stąd musi być widziany w podwójnym wymiarze: religijnym i historycznym. Wymiar religijny jest podstawą i naczelnym motywem zapowiedzi znaku, wymiar historyczny stanowi o jego charakterze znakowym czyli o jego czytelności. Wymiar religijny, czyli zbawczy znaku Emmanuela zawiera się w samym imieniu dziecka „Bóg-z-nami”. H. W. W o lff mniema, że to imię jest zaktualizowaniem "staroizraelskiego wezwania do świętej wojny i w tym wypadku ogłasza obietnice ocalenia, Frieden, str. 42 n.

${ }_{15}$ Perykopa Iz 7, 10-14 nosi ślady różnych przeróbek tekstu. Aparat krytyczny Kittela podaje 14 wariantów tekstowych. Tutaj bierzemy pod uwaga jedynie te, które naszym zdaniem, są wyraźnym świadectwem przeobrażeń tekstu dyktowanych potrzebą jego zrozumienia w nowej sytuacji historycznej. 
przekład LXX w którym zwrot „młoda niewiasta” jest zastąpiony słowem „dziewica"; w wierszu 14 wariant hebrajski formy czasownikovej $w^{e}$ qarat pr ponujący lekturę $w^{e}$ qora' = "zostanie nazwany" ub "nazwie się go"; wreszcie w wierszu 17 glossa „króla Asyrii” dodana w TM na kıńcu wiersza. a) Dodatek w w. 17 znajduje się w TM i we wszystkich przekładach, ale $z$ punktu widzenia składni hebrajskiej jest $\mathrm{w}$ tym kontekście obcym, sztucznie dodanym elementem. Większość komentatorów uważa go za glossę nieużyteczną, utrudniającą zrozumienie sensu samej wyroczni ${ }^{16}$. Jest to jednak opinia apriorystyczna, nie uwzględniająca faktu, że glossa końcowa w w. 17 zachowana jest zarówno w tekście oryginalnym jak i we wszystkich starożytnych przekładach. Należy przyznać, że owa nieporadna stylistycznie glossa zmienia zasadniczo sens wyroczni-znaku. Jeśli w ustach Izajasza była to wyrocznia ocalenia, po dodaniu glossy stała si z ona wyrocznią nieszczęścia. Nowy jej sens jest następujący: zanim Emmanuel rozpocznie wykonywanie władzy, spustoszona zostanie ziemia nieprzyjaciół Judy, a na dynastię Dawida i na królestwo, Pan sprowadzi czasy, jakich nie było od schizmy, (sprowadzi) króla Asyrii. Naszym zdaniem ta glossa jest świadectwem procesu hermeneutyki transformacyjnej przekształcającej wyrocznię prorocką. Prawdopodobnie to przekształcenie pochodzi $\mathrm{z}$ okresu najazdu asyryjskiego i jest dziełem tych kompilatorów słów Izajasza, którzy zebrali razem cztery wyrocznie nieszczęścia w ww. 18-25 rozdziału siódmego, rozpoczynające się każda formułą „w owym dniu", a następnie połączyli je $z$ przekształconą znaczeniowo wyrocznią-znakiem w ww. 16-17. W ten jednak sposób znak Emmanuela został przesunięty chronologicznie o ponad trzydzieści lat naprzód, a samo panowanie Emmanuela nie miałoby nastąpić zaraz po spustoszeniu Syrii i Efraima, lecz dopiero później, po najeździe asyryjskim. Reinterpretacja, jak widzimy, nie zmienia charakteru i znaczenia zapowiedzi zbawczej interwencji Boga w osobie Emmanuela, lecz przesuwa bardziej w przyszłość okoliczności wskazujące na spełnienie się tej interpretacji.

b) Ślady dalszych przeobrażeń powodowanych potrzebą dostosowania tekstu do nowej rzeczywistości znajdujemy w dwu wariantach w w. 14, czyli tym razem w samej zapowiedzi narodzenia Emmanuela. Przykład LXX jest świadectwem bardzo istotnego przeobrażenia nie tyle sensu, ile charakteru tej zapowiedzi. Pamiętając, że na przełomie III/II w. przed Chr. język grecki znał słowo odpowiadające hebrajskiemu (almah i że tłumacze LXX mogli oddać je przez neanis;

16 Jednak nie wszyscy autorzy sądzą, że ten dodatek jest glossą pozbawioną znaczenia. R. Kilian, Die Verheissung Immanuels, Jes 7, 14 (SBS 35), Stuttgart 1968, str. 15 i N. L o h f in k, Bibelauslegung im Wandel, str. 186, uważają tę glossę za bardzo starożytną. R. P. Carrol, When the Prophecy Failed, twierdzi, że glossa w w. 17 jest bardzo ważnym elementem znaczeniowym tego tekstu i pochodzi z okresu, w którym został on po raz pierwszy zinterpretowany, str. 139. 
musimy przyznać, że wybór słowa parthenos nie był sprawą przypadku ${ }^{17}$. Nie można też zadowolić się opinią, podtrzymywaną przez niektórych biblistów, że tlumacze użyli słowa parthenos, by $\mathrm{w}$ ten. sposób podkreślié stan dziewiczej młodej niewiasty przed naturalnym poczęciem i porodzeniem przez nią przyszłego syna ${ }^{18}$. Zarówno przypadek jak i powyższy motyw nie mogły być wystarczającą przyczyną do tak ważnego przeobrażenia tekstu. Bardziej słusznym wydaje się mniemanie, że tłumaczenie LXX odzwierciedla nową interpretację słowa halalmah rozpowszechnioną $\mathrm{w}$ tym okresie przynajmniej w kołach aleksandryjskich. Pozostając przy opinii, że istota znaku w proroctwie o Emmanuelu tkwi w określeniu okoliczności historycznych towarzyszących tej postaci, konsekwentnie utrzymujemy, że przyczyną przekształcenia tekstu była potrzeba ponownego zaktualizowania znaku w proroctwie. Okoliczności historyczne, o których mowa w ww. 16-17, przestały być aktualne po upływie trzech lub czterech wieków i tym samym proroctwo o Emmanuelu pozbawione zostało towarzyszącego mu znaku. Nadając nową treść słowu „młoda niewiasta", hermeneuci ze środowiska aleksandryjskiego uczynili $z$ tej postaci znak zapowiedzi zbawczej interwencji w osobie Emmanuela. „Młoda niewiasta" mająca porodzić Emmanuela ustąpiła miejsca "dziewicy" - matce Emmanuela, która w ten sposób stała się znakiem nadzwyczajnym, nieokreślonym czasowo, ale łatwym do rozpoznania. Według tej nowej, przekształconej wersji proroctwa, już nie określone wydarzenia historyczne poprzedzać będą panowanie Emmanuela, lecz dziewica-matka będzie znakiem jego narodzenia. Proces hermeneutyczny nie zmienił w niczym zapowiedzi zbawienia, lecz ubogacił ją nową funkcją: funkcją znaku. Tym samym uznano wyrocznię w ww. 16-17 jako słowo prorockie należące do przeszłości i pozbawione swej aktualności historycznej.

c) Trzeci wariant dotyczy czasownika qara', który w tekście masoreckim posiada jedną formę spółgłoskową, lecz może być wokalizowany w podwójny sposób: weqara'ta = „ty, królu, nazwiesz go", lub $w^{e}$ qara't = "ona nazwie go". Starożytne przekłady posiadają

17 W dwóch wypadkach 'almah hebrajskie zostało oddane przez parthenos, w Rdz 24, 43 i Iz 7, 14, i w obydwu wypadkach trudno zgodzić się na czysty przypadek znajdujący się u źródeł tej zamiany znaczeniowej. W Rdz 24, 43 chodzi o młodą dziewczynę Rebekę, którą poślubi Izaak. Należałoby zapytać, dlaczego tłumacze greccy użyli słow parthenos zamiast neanis dla określenia Rebeki. Jest godnym uwagi, że nazwano ją parthenos jedynie w tym kontekście (sprawozdanie Eleazara), a nie w opowiadaniu równoległym, $\mathrm{Rdz} 24,11-14$. Komentatorzy zazwyczaj nie zwracają uwagi na tę różnicę, zob. np. C. W estermann, Genesis (Biblischer Kommentar. Altes Testament), Bd I (2), Neukirchen 1981, ad locum.

18 Tak właśnie sądzi R. E. B r ow n, The Birth of the Messiah, London 1977, który wyjaśnia problem jednym zdaniem: "chodzi tu o niewiastę, która jest obecnie dziewicą i która pocznie (w naturalny sposób po rozpoczęciu współżycia z mężem) dziecko Emmanuela", str. 149. 
świadectwa obydwu wersji, ale kryterium lectio difficilior każe opowiedzieć się za drugą wersja, jako bardziej prawdopodobną ${ }^{19}$. Poza tym nie można wykluczyć podejrzenia, że forma interpretująca czasownik w 2 os. 1. p. rodz. męskiego mogła wyniknąc z polemicznej egzegezy judaistycznej, która w ten sposób pragnęła wytrącić egzegezie chrześcijańskiej argument skrypturystyczny o dziewiczym poczęciu i narodzeniu Chrystusa. Wariantem bardziej istotnym i nie pozbawionym znaczenia jest forma $w^{e} q \circ a^{\prime}=$ "on zostanie nazwany", lub bezosobowo „nazwie się go" poświadczona przez rękopisy z Qumran. Znaczeniowo bliskim tego wariantu jest cytat grecki u Mt 1, 23 "I nazwą go imieniem Emmanuel". Takie przekształcenie tekstu wskazywałoby na podmiot zbiorowy zapowiedzi narodzin Emmanuela, ale o przyczynach powodujących te interpretacje powiemy za chwile.

\section{PROROCTWO IZAJASZA W NURCIE TRADYCJI RELIGIJNEJ IZRAELA}

Jeśli proponowany przez nas sposób reinterpretacji tekstu Izajasza jest słuszny, pozostaje do wyjaśnienia sytuacja wyjściowa omawianego tekstu, a mianowicie dziwna konstrukcja składniowa proroctwa nie odpowiadająca jego konstrukcji znaczeniowej. Pragniemy pogłębić to zagadnienie odnosząc się raz jeszcze do jednego $z$ czterech działań hermeneutycznych wskazanych przez P. Ricoeura, a mianowicie działania mającego na celu przełamanie dystansu, jaki rodzi się między wiarą i formułą językową. P. Ricoeur słusznie zauważa, że każde orędzie biblijne, a prorockie w szczególności, można zawsze sprowadzić do jednej lub większej ilości podstawowych formuł wiary Izraela. Te same formuły stanowią podstawę wszystkich wyroczni, modlitw, opisów historycznych czy dokumentów o charakterze prawniczym. Jednak wyznanie wiary wypowiedziane w tekstach biblijnych nie może być oddzielone od swej szaty językowej, czyli od sposobu formułowania jej, właściwego każdemu autorowi. Wyznanie wiary raz sformułowane i utrwalone na piśmie pozostaje niezmienione, podczas gdy sama wiara podlega nieustannemu rozwojowi w miarę przeobrażeń społecznych, językowych i kulturowych. W ten sposób tworzy się swoiste napięcie między ciągle nowych sposobem wyrażania wiary i każdą formą językową raz ustaloną i utrwaloną na piśmie. Zadaniem procesu hermeneutycznego jest eliminować te napięcia pjprzez tworzenie ciągle nowych form językowych wyrażających każdorazowe doświadczenie wiary i mających na celu ubogacenie istniejąjących już formuł. Ogromną rolę, twierdzi P. Ricoeur, odgrywają tu tradycje teologiczne, które obejmują swym potężnym nurtem i doświadczenia wiary i funkcje języka, nadając im jeden i ten sam kie-

19 Zob. P. A uvra y, Isaïe, str. 329. 
runek ${ }^{20}$. Rozwój form językowych wyrażających wiarę jest również owocem procesu hermeneutycznego, który $\mathrm{w}$ tym wypadku nie zmienia tekstu, lecz przedłuża i ubogaca jego treść przy pomocy nowych sformułowań.

Formą językową zastosowaną przez Izajasza w zapowiedzi znaku Emmanuela jest znana w ST tzw. formula nadania imienia ${ }^{21}$. Brzmi ona następująco: „X poczęła i porodziła syna i nadała mu imię $\mathrm{Y}$, gdyż mówiła”, lub samo „gdyż" bez słowa „mówiła”; po spójniku $k i=$,gdyż" lub ,gdyż mówiła" następuje normalnie uzasadnienie nadanego imienia. Najczęściej uzasadnienie jest oparte na wyjaśnieniu etymologicznym imienia. Przykład takiej formy i uzasadnienia imienia mamy u Iz 8, 3-4, gdzie imię nadaje ojciec, co jest nierzadko spotykane w ST, a w uzasadnieniu znajduje się słowo szelal etymolıgizujące jeden element złożonego imienia Maher-Szalal-Hasz-Baz. W Iz 7, 14-15 nie ma wyjaśnienia etymologicznego imienia Emmanuel, a sama formuła jest użyta do zapowiedzi znaku, a więc w niewłaściwej sobie funkcji. $Z$ drugiej strony obraz niewiasty mającej porodzić należy do tradycji znaków w ST, ale w takich wypadkach chodzi zawsze o niewiastę bezpłodną i to stanowi o naturze znaku: putwierdza on bowiem, że u Boga nie ma nic niemożliwego. U Izajasza rodząca lub mająca porodzić nie jest niewiasta bezpłodna, lecz przeciwnie, (almah, niewiasta młoda i zdolna do macierzyństwa; a zatem i w tym wypadku prorok odbiega od znanego $z$ tradycji schematu. Jeśli więc istota znaku, jak to już powiedzieliśmy, tkwi gdzie indziej, dlatego Izajasz posłużył się, w zapowiedzi znaku, obrazem niewiasty mającej porodzić i dlaczego użył formuły nadania imienia, zmieniając jednak jej funkcję?

By na to odpowiedzieć, przypomnijmy, że Izajasz nie jest jedynym prorokiem mówiącym o mającej porodzić niewieście. Podobne proroctwo znajdujemy $u$ współczesnego mu Micheasza ogłaszającego przyjście władcy w Izraelu, który ,wynijdzie z Betlejem Efrata w Judzie”, ale przedtem „(Pan) wyda ich aż do czasu, kiedy porodzi mająca porodzić" $(5,2)$. Mamy więc w teologiczneej tradycji judejskiej z VIII w. przed Chr. dwa proroctwa dotyczące prawdopodobnie tej samej osoby, zwanej u Izajasza Emmanuel, a u Micheasza môszel = „Władca", ale niezależne od siebie i sformułowane każde w sposób właściwy swemu autorowi. W obydwu wypadkach podkreśla się osobę mającą porodzić i w obydwu wypadkach nie ma wzmianki o nadzwyczajnych okolicznościach narodzenia. Istotnym jest, że w tajemniczym Emmanuelu czy Władcy spełnia się zbawcza interwencja Boga i że ma ona jakiś związek $\mathrm{z}$ domem Dawida: Izajasz zapowiada

20 Por. P. Ricoeur, Herméneutique philosophique et herméneutique biblique w: Exegesis, str. 217-221.

${ }^{21}$ Wyczerpująca analize tzw. formuły nadania imienia podaje J. Fichtner, Die etymologische Aetiologie in den Namengebungen der geschichtlichen Bücher des Alten Testaments, VT 6 (1956), 372-396. 
narodzenie i władzę Emmanuela jako znak dany domowi Dawida, Micheasz ogłasza narodziny władcy w Betlejem, mieście Dawida. Obydwa proroctwa dają wyraz wierze wspólnoty religijnej Judei z VIII wieku, którą można by ująć w następującej formule: Bóg udzieli zbawienia poprzez dynastię Dawida, a historycznie wypełni się ono $\mathrm{w}$ osobie dziecięcia narodzonego $\mathrm{z}$ niewiasty. Taka formuła musiała wyrosnąc z tradycji historycznych zawierających przykłady niewiast bezpłodnych, a dzięki wszechmocnej interwencji Boga wydających na świat wielkich mężów Bożych, jak Izaaak, Samson, Samuel, ale w swej istocie formuła ta pozostawała niezależna od poprzedzających ja przykładów i oryginalna w tym, że samo narodzenie dziecka nie miało być wynikiem specjalnej interwencji Boga na korzyść niepłodnej matki.

Trudno przypisać Izajaszowi autorstwo tej nowej formuly wiary, skoro znał ją również Micheasz. Tym jednak, co należy określić jako absolutną nowość w proroctwie Izajasza, jest niesłychanie śmiała forma językowa, w jakiej prorok ją wyraził. Izajasz skorzystał z zagrożenia czy wręcz rozpaczliwej sytuacji króla Achaza, by wyrazić swoją wiarę w zbawczą interwencję Boga za pośrednictwem domu Dawida, jako wydarzenie niezwłoczne i pewne. Boża oferta zbawienia jest bliska - głosi jego orędzie skierowane do następcy na tronie Dawida - oto wśród nas niewiasta mająca porodzić; znane jest imię jej dziecka zawierające w sobie pewność zbawienia: „Bóg z nami”; panowanie przychodzącego wiadcy jest bliskie a poprzedzi je zniszczenie ziemi twoich nieprzyjaciól i dobrobyt twego ludu. Prorok widri te wielkie wydarzenie jako obecne już i teraz; niejako uczestniczy w nim osobiście i dlatego zapowiada narodziny dziecka za pomoca formuły nadania imienia, jakby chciał powiedzieć, że ten uroczysty akt związany $z$ narodzinami jest już faktem dokonanym.

Izajasz nie zadowala się jednorazową zapowiedzią Emmanuela. W następnych proroctwach, wypowiedzianych być może już po zniszczeniu Syrii i Efraima powraca on trzykrotnie do postaci Emmanuela reinterpretując pierwszą zapowiedź. Prawdopodobnie wynikło to z potrzeby podtrzymania aktualności raz zapowiedzianego zbawienia, które nie spełniło się mimo zaistniałych okoliczności ukazanych przez proroka jako znak wiadzy Emmanuela ${ }^{22}$. Izajasz nie odwołal pierwszego proroctwa, lecz przeciwnie, w trzech następnych wyroczniach - Emmanuelu potwierdził jeszcze bardziej pierwszą wyrocznię wyjaśniając bliżej poszczególne jej elementy. Np. w 9, 5 prorok ogląda niejako narodzenie $\mathrm{z}$ niewiasty $\mathrm{w}$ perspektywie bardziej uniwersali-

22 R. P. Carrol poświęca swą monografię, When the Prophecy Failed, problematyce proroctwa zapowiadającego jakieś wydarzenie $w$ niedalekiej przyszłości i spełniającego się tylko częściowo. Analizując przykład Iz 7, 10-17 autor stwierdza, że należy go zaliczyé do tych wyroczni prorockich, których spełnienie było uwarunkowane odpowiedzią wiary ze strony króla i wspólnoty Izraela. W tym wypadku zapowiedź nie spełniła się w przyszłości wskazanej przez proroka z powodu odrzucenia przez króla i przez naród zbawczej oferty Boga, str, 140. 
stycznej i wyraża jeszcze mocniej swe przekonanie o bliskości ofiarowanego daru: „Dziecię nam się narodziło. Syn został nam dany... zazdrosna miłość Pana Zastępów tego dokonała". W 8, 10 i szczególnie w 11, 1-9 Izajasz kontempluje czasy zapowiedzianego władcy i chociaż bliżej nie określa momentu ich nadejścia, opisuje je w taki sposób, jakby sam był tego naocznym świadkiem. Trzy proroctwa - Emmanuelu następujące po zapowiedzi jego narodzin są przykładem interpretacji przez samego proroka, który precyzuje w nich coraz bardziej istotę zbawczej interwencji Boga. Punktem centralnym zainteresowania jest osoba władcy, który narodzi się w dynastii dawidowej $(9,1)$, oraz charakter jego wladzy i dobrodziejstwa stąd płynące dla Judy i dla wszystkich narodów. Należy dodać, że w tych wyroczniach reinterpretujących nie ma mowy o matce dziecka, co znaczyłoby - naszym zdaniem - że ten element proroctwa został zamknięty znaczeniowo, tzn. żadna. forma językowa nie była w stanie dodać doń nowych treści ponad te, które były znane z samej formuły wiary. Innymi słowy, Izajasz wyraził ten element formuły wiary - tj. zapowiedź niewiasty mającej porodzić - jako niewiadomą już w pierwszym proroctwie o Emmanuelu i tym samym zamknąl możliwość bliższego określenia niewiasty w następnych wyrazach językowych interpretujących to proroctwo ${ }^{23}$. Kierunek interpretacyjny nadany przez Izajasza znalazł swój wyraz dwa wieki później w proroctwach Jeremiasza, 23. $5 \mathrm{n}$ i 33,15 oraz po niewoli u proroka $\mathrm{Za}$ chariasza, 3, 8; 6, $12 \mathrm{n}$. Podobnie jak w tekstach Izajasza, wyrocznie obydwu proroków mówią o wladcy $z$ domu Dawida i ukazują podobny charakter jego władzy; jednak nie ma w nich tak szerokiego horyzontu jak $\mathrm{w}$ interpretacji Izajasza i podobnie jak $u$ tego ostatniego nie ma w nich wzmianki o matce zapowiedzianego władcy.

Rzecz wygląda inaczej w wypadku Micheasza, którego forma językowa różni się od Izajaszowej. Niektórzy twierdzą, że liczne przeróbki późniejsze interpretujące pierwotne proroctwo wpłynęły na aktualną jego formę i że komentarzem do niej jest inna wyrocznia Micheasza zawarta w 4, 9-10 ${ }^{24}$. Jeśli ta opinia jest słuszna, niewiastą „mająca porodzić” w Mi 5, 2 byłaby Córa Syjonu wijąca się z bólu jak ta, „która ma porodzić" $(4,10)$. Forma językowa w proroctwie Micheasza otwarłaby $w$ ten sposób możliwość dla reinterpretacji osoby mającej porodzić. Motyw Syjonu jako matki niepłodnej, która porodziła, pojawia się u Deuteroizajasza 54,1 , a następnie jako matki rodzącej, która w jednym dniu wydała na świat wszystkie swe dzieci u Tritoizajasza 66, 6-8. Trudno powiedzieć, jak dalece te teksty mogą

23 Należy przez to rozumieć, że Izajasz nie zawarł $\mathrm{w}$ zapowiedzi matki Emmanuela żadnego elementu, który pozwoliłby na powiązanie jej $z$ innymi szczegółami znanymi słuchaczom, lub możliwymi do poznania. Brak otwarcia na nowe znaczenia sprawia, że nie moźna poddać tej zapowiedzi dalszej interpretacji bez konieczności zmienienia jego podstawowego sensu.

24 Zob. dobry i znany komentarz do Księgi Micheasza w: B. R e n a u d, La formation du livre de Michée (Etudes Bibliques), Paris 1977, str. 246. 
być reinterpretacja Micheasza, ale jest rzeczą pewną, że u końca epoki starotestamentalnej istniała taka reinterpretacja matki Syjon mającej porodzić Emmanuela. Pośrednio świadczy o tym wspomnion wyżej wariant w rękopisach qumrańskich, który interpretuje czasownik qara' w Iz 7, 14 jako 3 os. 1. p. w formie Pual: qora' = ,z zstanie nazwany" lub ,nazwie się go". Bezpośrednio świadczy o tym fragment hymnu z Qumran (1 QH 3, 1-18) kwalifikujący cierpienia ludu Izraela jako „,boleści rodzenia syna”, który będzie „przedziwnym doradcą" i wybawicielem ${ }^{25}$. Wyraźna aluzja do proroctwa o Emmanuelu u Iz 9, 5 wskazuje na to, że hymn qumrański interpretuje tu narodzenie Emmanuela, którego matką jest osoba zbiorowa, lud Izraela. Reinterpretacja proroctwa Micheasza rozwinęła się, jak widzimy, w kierunku różnym od Izajaszowej zapowiedzi narodzin Emmanuela.

W obydwu jednak wypadkach rozwój poszczególnych elementów tej wspólnej obu prorokom formuly wiary nie spowodował przeciwsțawienia sobie tych elementów, lecz przeciwnie, doprowadził do ich wzajemnego uzupełnienia się. Obraz Syjonu, matki bezplodnej a później rodzącej w jednym dniu wszystkie swe dzieci, użyczył szaty językowej do rozwinięcia zapowiedzi Micheasza o końcu udręki Izraela, kiedy „porodzi mająca porodzić”. Hermeneutyka transformatywna przekształcająca znaczenie czasownika qara’ w Izajaszowej zapowiedzi narodzin Emmanuela pozwoliła przybliżý tę interpretację rodzącej niewiasty jako matki Izraela do proroctwa Izajasza.

Z drugiej strony uwypuklenie narodzin Emmanuela w Iz 7, 14-17 jako bliskiej zbawczej interwencji Boga ofiarowanej dynastii Dawida pozwoliło rozwinąc crzymioty, charakter i zakres władzy Emmanuela panującego niepodzielnie i na zawsze nad Judą i nad wszystkimi narodami. Interpretacja istoty znaku w tym proroctwie dokonana dzięki podwójnej interwencji hermeneutyki transformacyjnej, tzn. glossa w wierszu 17 i parthenos LXX w wierszu 14, pozwoliła na ostateczne określenie znaku w osobie dziewicy mającej porodzić Emmanuela. Ten podwójny charakter matki Emmanuela, indywidualny i fizyczny $w$ osobie matki-dziewicy oraz zbiorowy i metaforyczny w obrazie ludu Izraela, znalazł swój pełny wyraz w tekście nowotestamentalnym ujmującym w jedno obydwa kierunki interpretacyjne formuły wiary $z$ okresu Izajasza i Micheasza, a mianowicie w cytacie ze ST przytoczonym przez św. Mateusza na dowód narodzin Mesjasza:

„Oto Dziewica pocznie i porodzi syna, któremu nadadzą imię Emmanuel" (1,23).

Rzym

KS. ANDRZEJ STRUS SDB

25 Zob. J. C armigna c, Les textes de Qumràn traduits et annotés, I, Paris 1961, str. 194 i M. Delcor, Les Hymnes de Qumran (Hadayot), Paris 1962, str. 118. 